\title{
Correction to: LncRNA AK023391 promotes tumorigenesis and invasion of gastric cancer through activation of the PI3K/Akt signaling pathway
}

Yanxia Huang ${ }^{1}$, Jing Zhang ${ }^{1 *}$, Lidan Hou ${ }^{2}$, Ge Wang ${ }^{1}$, Hui Liu' ${ }^{1}$, Rui Zhang ${ }^{1}$, Xiaoyu Chen ${ }^{1}$ and Jinshui Zhu ${ }^{1 *}$

\section{Correction to: J Exp Clin Cancer Res 36, 194 (2017)}

https://doi.org/10.1186/s13046-017-0666-2

Following publication of the original article [1], the authors identified an error in Fig. 5; specifically the HGC-27 cell line in figure 5A. The correct figure is given below.

\footnotetext{
Author details

'Department of Gastroenterology, Shanghai Jiao Tong University Affiliated Sixth People's Hospital, No. 600 Yishan Road, Shanghai 200233, China.

2Department of Gastroenterology, Shanghai Ninth People's Hospital, Shanghai Jiao Tong University School of Medicine, Shanghai, China.
}

Published online: 12 August 2020

\section{Reference}

1. Huang, et al. LncRNA AK023391 promotes tumorigenesis and invasion of gastric cancer through activation of the PI3K/Akt signaling pathway. J Exp Clin Cancer Res. 2017;36:194.

The original article can be found online at https://doi.org/10.1186/s13046017-0666-2.

* Correspondence: jing5522724@vip.163.com; zhujs1803@163.com

'Department of Gastroenterology, Shanghai Jiao Tong University Affiliated Sixth People's Hospital, No. 600 Yishan Road, Shanghai 200233, China

Full list of author information is available at the end of the article

(c) The Author(s). 2020 Open Access This article is licensed under a Creative Commons Attribution 4.0 International License, which permits use, sharing, adaptation, distribution and reproduction in any medium or format, as long as you give appropriate credit to the original author(s) and the source, provide a link to the Creative Commons licence, and indicate if changes were made. The images or other third party material in this article are included in the article's Creative Commons. licence, unless indicated otherwise in a credit line to the material. If material is not included in the article's Creative Commons licence and your intended use is not permitted by statutory regulation or exceeds the permitted use, you will need to obtain permission directly from the copyright holder. To view a copy of this licence, visit http://creativecommons.org/licenses/by/4.0/ The Creative Commons Public Domain Dedication waiver (http://creativecommons.org/publicdomain/zero/1.0/) applies to the data made available in this article, unless otherwise stated in a credit line to the data. 


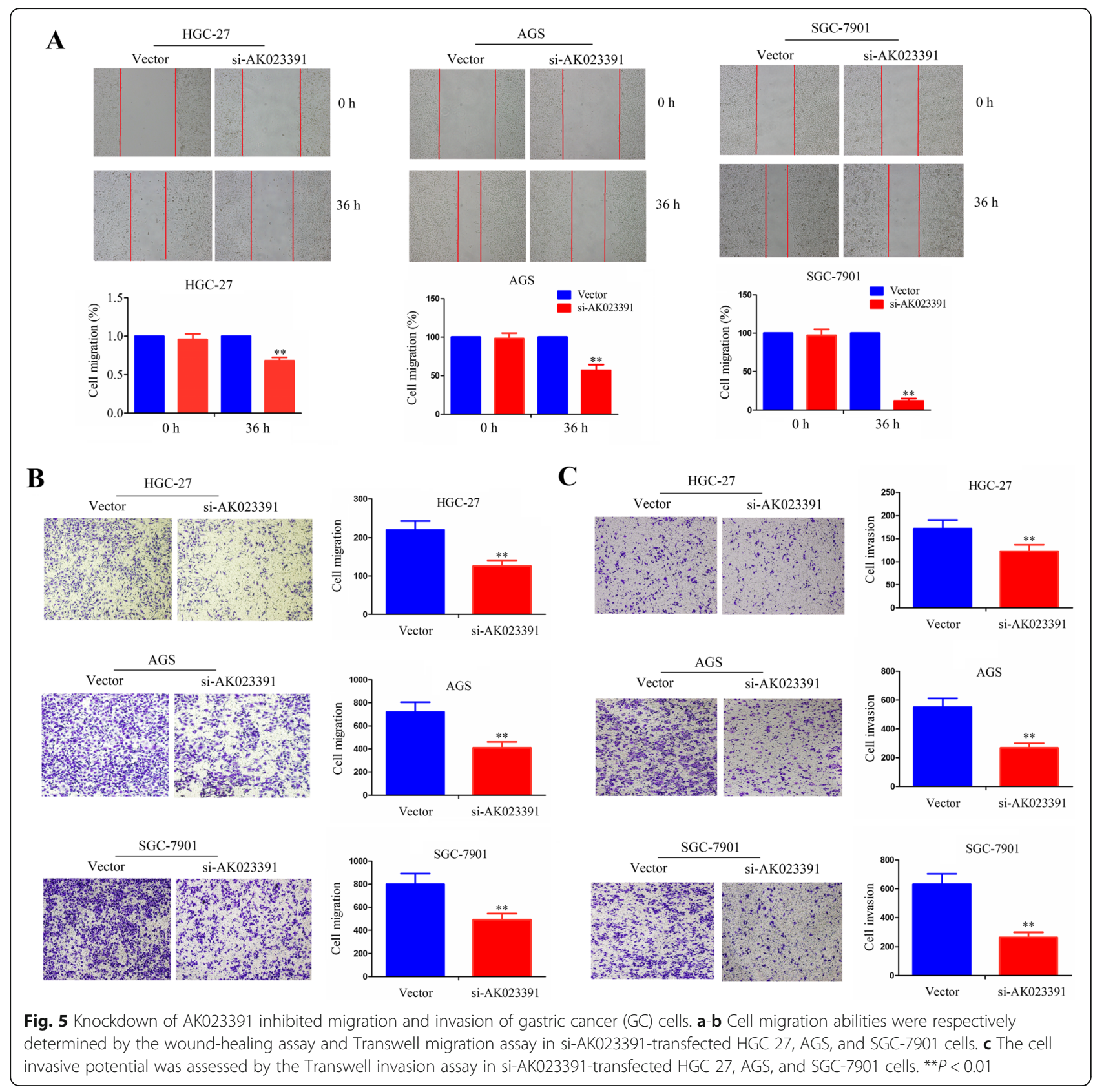

